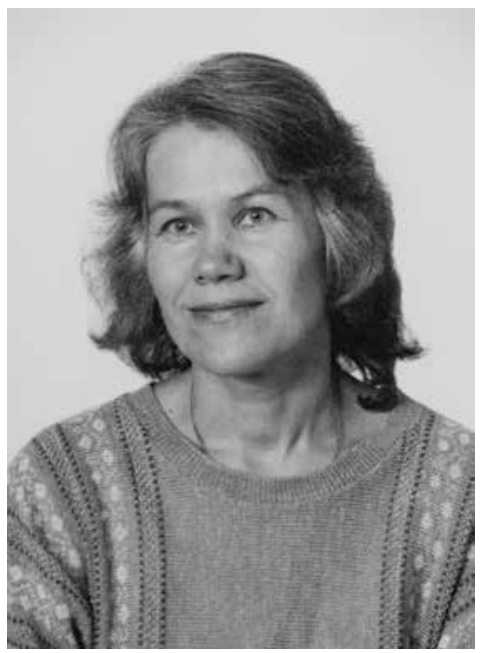

\title{
Riitta Huuhtanen IN MEMORIAM
}

Kuopion yliopiston pitkäaikainen kirjastonjohtaja Riitta Liisa Huuhtanen menehtyi äkilliseen sairauskohtaukseen Kuopiossa 30. lokakuuta. Hän oli 79-vuotias, syntynyt Lapinlahdella I6. kesäkuuta I940. Hän aloitti koulunkäyntinsä Lapinlahdella ja kirjoitti ylioppilaaksi Kuopion yhteislyseon lukiosta.

Huuhtanen valmistui Jyväskylän yliopistosta vuonna 1967. Hän suoritti kirjastotutkinnon Yhteiskunnallisessa korkeakoulussa vuonna I965. Tieteellistä kirjastouraa varten häntä valmisti Suomen kirjallisuuspalveluseuran järjestämä Informaatiopalvelun kurssi, jonka Huuhtanen suoritti vuonna I97I.

Informaatiopalvelun kurssi koulutti Suomeen ensimmäisiä nykyaikaiseen tietopalveluun valmennettuja informaatikoita, jotka alkoivat käyttää tietokoneita ja niiden mahdollisuuksia kirjastotyössä. Huuhtanen olikin muiden aikalaistensa joukossa rakentamassa Suomeen tieto- ja viestintätekniikkaan nojaavia tieteellisiä kirjasto- ja tietopalveluita ja aloittamassa digitaalisen kirjastotoiminnan murrosta. Hän oli mukana useissa tuon ajan suunnittelutoimikunnissa tai suunnittelijana hankkeissa, joissa alettiin luoda tietotekniikkaan perustuvaa tieteellistä kirjastoverkkoa ja sen palveluita.

Huuhtanen aloitti kirjastouransa jo opiskeluaikanaan ja työskenteli kaikkien niiden korkeakoulujen kirjastoissa, joissa opiskeli. Ensimmäinen vakinainen tehtävä oli Jyväskylän yliopiston kirjastossa. Kuopion korkeakoulussa hän aloitti vuonna I977, kävi välillä Joensuun korkeakoulussa ja palasi vuonna 1983 Kuopion korkeakouluun, jossa hänet valittiin kirjastonjohtajaksi. Tässä tehtävässä hän oli aina eläkkeelle siirtymiseensä saakka vuoteen 2003. 
Huuhtasen aikana Kuopion yliopiston kirjastossa otettiin käyttöön uudenaikaisia tietopalveluita. Hän oli aktiivisesti mukana uudistamassa kansalliseen käyttöön hankittuja yhteisiä kirjastojärjestelmiä ja ottamassa käyttöön internetin tarjoamia mahdollisuuksia, sekä viestintään että tieteelliseen tiedonhankintaan. Itse hän muisteli myös yliopistokirjastojen neuvoston alkuaikoja, "Eskon enkeleitä", kuten heitä tuon ajan televisiosarjan mukaan kutsutiin. Kirjastoyhteistyö oli hänelle merkittävä asia.

Kuopion yliopistossa avattiin vuonna 1998 Suomen ensimmäinen Oppimiskeskus, jota Riitta Huuhtanen oli ollut suunnittelemassa vuosikymmenen alusta lähtien. Se vastasi haasteisiin, joita tieto- ja viestintätekniikka asettivat opiskelijoille. 2000-luvun alkupuolella hän toimi projektinjohtajana TieDot-hankkeessa, mikä oli seitsemän yliopiston yhteishanke. Hankkeessa tehtiin tiedonhaun verkkokursseja tukemaan informaatiolukutaitoa.

Huuhtasella oli useita merkittäviä alan luottamustehtäviä. Hän oli mukana sekä Joensuun että Kuopion yliopiston hallituksissa, Suomen tieteellisen kirjastoseuran hallituksessa ja opetusministeriön asettamassa elektronisen kirjaston ohjausryhmässä. Lisäksi hän oli aktiivinen toimija FinELibin ja Linnea2 -yhteistyön kehittämisessä, edelliseen hän houkutteli Kuopion yliopiston rehtoreita puheenjohtajiksi ja samalla lobbasi tieteellisten kirjastojen digitaalista murrosta tieteentekijöille.

Merkittävin yksittäinen saavutus ja rooli Huuhtasella oli Varastokirjastotoiminnan kehittämisessä ja vakiinnuttamisessa keskeiseksi suomalaisen kirjastoverkon yhteiseksi palveluksi, josta tuli esimerkki vastaavalle toiminnalle kansainvälisestikin. Huuhtanen toimi sekä Varastokirjaston suunnittelutoimikunnan että johtokunnan puheenjohtajana. Vielä eläkevuosinaan hän osallistui aktiivisesti keskusteluun Varastokirjaston roolista suomalaisessa kirjastoverkossa.

Huuhtasen koulutusalat, historia ja suomen kieli, näkyivät hänen toiminnassaan sekä kirjailijana että kotiseututyön tekijänä. Jälkimmäisestä hänet palkittiin Suomen kotiseutuliiton ansiomitalilla. Eläkevuosinaan hän oli kysytty paikallisopas Kuopiossa vierailleille turisteille, ja hänen asiantuntevat opastuksensa tekivät kuopiolaisen historian eläväksi. Hän julkaisi kirjoja sekä kirjastojen historiasta että paikallishistoriasta, viimeisimpänä työnään kesällä 20I 8 julkaistu kirja Elämää vanhalla Haapaniemellä - Villa Rullan tarina. Villa Rulla oli Huuhtasen eläkepäivien rakas asuinpaikka.

\section{JARMo SAARTI}

Arja Juntunen

Aino Taskinen

Itä-Suomen yliopisto

Kirjoittajat ovat Riitta Huuhtasen ystäviä ja työtovereita

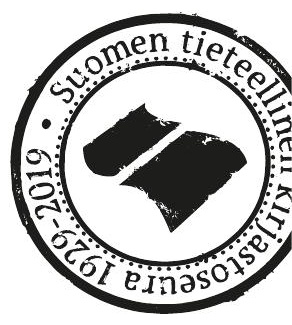

